ISSN 2413-0877 Volume 2 (2015) 139-145

The 3rd International Conference on Biological Science 2013

(The 3rd ICBS-2013)

\title{
Analysis of Genetic Diversity of Indonesia Rodent Tuber (Typhonium flagelliforme Lodd.) Cultivars Based on RAPD Marker
}

\author{
Danny Laurent ${ }^{1}$, Nesti F. Sianipar ${ }^{2}$, Chelen ${ }^{1}$, Listiarini' ${ }^{1}$, and Ariandana Wantho ${ }^{3}$. \\ 'Students of Biology Department, Faculty of Science and Mathematics, Universitas Pelita Harapan. \\ JI. MH. Thamrin Boulevard 1100, Lippo Karawaci, Tangerang - Banten 15811 \\ ${ }^{2}$ Biology Department, Faculty of Science and Mathematics, Universitas Pelita Harapan. \\ JI. MH. Thamrin Boulevard 1100, Lippo Karawaci, Tangerang - Banten 15811 \\ ${ }^{3}$ Student Alumna of Biology Department, Faculty of Science and Mathematics, Universitas Pelita Harapan. \\ JI. MH. Thamrin Boulevard 1100, Lippo Karawaci, Tangerang - Banten 15811 \\ Correspondence author :dylluvzjc@gmail.com
}

\begin{abstract}
Rodent tuber (Typhonium flagelliforme Lodd.) is a plant from Araceae family. The plant has high medical potential as anti-cancer agent. The information regarding Indonesian rodent tuber's genetic diversity is not available yet. Genetic information is very important for the development of rodent tuber as medicinal plant. In this research, genetic diversity and genetic distance of three Indonesian rodent tuber's cultivars, from Bogor, Pekalongan, and Medan, were analyzed by using RAPD molecular markers. The data obtained was analyzed by NTsys software. Out of 16 primers used in the study, the 12 primers were found to be polymorphic. There were 83 bands of DNA obtained and 31 of them were polymorphic. Dendogram analysis of the three rodent tuber cultivars showed that these cultivars were clustered into two clusters. The first cluster consists of rodent tuber Bogor and Medan. The second cluster consists of rodent tuber Pekalongan. The coefficient of similarity ranged from 0.81 to 0.87 . The highest coefficient of similarity was 0.87 , which was detected between rodent tuber Pekalongan and Medan. The lowest coefficient of similarity was 0.81 , which was detected between rodent tuber Bogor and Pekalongan. Among these three cultivars of rodent tuber, cultivar Bogor was exclusively different.
\end{abstract}

Key words: Indonesia-rodent tuber, genetic diversity, RAPD-marker

\section{INTRODUCTION}

Rodent tuber (Typhonium flagelliforme Lodd.) is a herbal plant from Araceae family (Surachman, 2009). Several researches had shown the plant's activity towards cancer cells, such as breast cancer, ovarian cancer (Syahid \& Kristina, 2009; Nurrochmad, 2011), leukemia (Mohan et al., 2011), and lung cancer (Chan \& Muhammad, 2005). Phyto-chemical analysis showed that the plant contained alkaloid, steroid, flavonoid, glycoside (Surachman, 2009), and cerebroside (Huang et al., 2004).

Rodent tuber reproduce vegetatively through tuber separation, therefore the plant generally has low genetic diversity (Syahid \& Kristina, 2007). The information regarding Indonesian rodent tuber's genetic diversity is not available yet. Genetic information is very important for the development of Indonesian rodent tuber as medicinal plant.

Random Amplified Polymorphic DNA (RAPD) molecular markers are a type of polymerase chain reaction (PCR) based molecular markers (Fauza et al., 2007). This molecular technique uses random oligonucleotide primers to amplify random regions in the genome. The polymorphism is shown by the presence or absence of DNA bands after separation by electrophoresis. These DNA bands act as dominant markers (Semagn et al., 2006). RAPD markers had been used to detect diversity of plants, such as Vigna mungo (L.) Hepper

ISSN 2413-0877 (C) 2015 The Authors.

Published by KnowledgeE Publishing Services This is an open access article under the CC BY-NC-ND license (http://creativecommons.org/licenses/by-nc-nd/4.0)

Selection and Peer-review under responsibility of the 3rd ICBS-2013

Doi http://dx.doi.org/10.18502/kls.v2i1.133 
(Arulbarachandran et al., 2010) dan Arachis hypogaea L. (Bhagwat et al. 1997).

This study aimed to analyze the genetic diversity of three Indonesian rodent tuber cultivars from Bogor, Pekalongan, and Medan by using RAPD molecular markers.

\section{MATERIALS AND METHODS}

\section{Plant Materials}

Three cultivars of rodent tubers were obtained from three different locations, which were Bogor (West Java Province), Pekalongan (Central Java Province), and Medan (North Sumatra Province). The plants were then kept in the greenhouse of Universitas Pelita Harapan.

\section{DNA Isolation}

The DNA was isolated from leaves of rodent tuber. One $\mathrm{ml}$ of CTAB buffer was added to 200 gram of rodent tuber leaves. The leaves were then homogenized by using mortar and pestle. Homogenized samples were incubated in $65^{\circ} \mathrm{C}$ for 45 minutes by using waterbath. Chloroform isoamyl alcohol $500 \mu \mathrm{l}(24: 1)$ were then added to the samples. The samples were centrifuged for 1 minute at $13000 \mathrm{rpm}, 700 \mathrm{il}$ of the upper aqueous phases were moved to different tubes. NaOAc $70 \mu \mathrm{l}$ and cold isopropanol $700 \mu \mathrm{l}$ were then added to the samples. The samples then incubated for 30 minutes in $-30^{\circ} \mathrm{C}$, followed by 10 minutes of centrifugation at $13000 \mathrm{rpm}$. The pellets obtained were washed with $500 \mu \mathrm{l}$ ethanol $70 \%$ and ovendried. Resuspension were done in TE buffer $200 \mathrm{il}$. The DNA samples were further treated with $5 \mu$ l of RNAse and incubated at $37^{\circ} \mathrm{C}$ for an hour. The concentration and purity of the DNA samples were determined by using electrophoresis in $1 \%$ agarose and spectrophotometry.

\section{RAPD Analysis}

The DNA samples were amplified using 16 decamer primers. The composition of PCR reaction used is shown in Table 1. Amplification reaction was done by using PCR with 45 thermal cycles: predenaturation at $95^{\circ} \mathrm{C}$ for 2 minutes, 7 cycles of denaturation-annealingextension $\left(95^{\circ} \mathrm{C} 1\right.$ minute, $37-34^{\circ} \mathrm{C} 1$ minute, $72^{\circ} \mathrm{C} 3$ minutes), and 38 cycles of denaturation-annealing-extension $\left(95^{\circ} \mathrm{C} 1\right.$ minute, $34^{\circ} \mathrm{C} 1$ minute, $72^{\circ} \mathrm{C} 3$ minutes), followed by final extension at $72^{\circ} \mathrm{C}$ for 7 minutes, and storage at $4^{\circ} \mathrm{C}$. PCR products were separated by using $1 \%$ agarose electrophoresis. Visualization was done with ethidium bromide $(\mathrm{EtBr})$ staining and UV illumination.

Table 1. Composition of PCR-RAPD Reaction

\begin{tabular}{lll}
\hline Components & Volume $(\mu \mathrm{l})$ & Final Concentration \\
\hline Template DNA $(100 \mathrm{ng} / \mu \mathrm{l})$ & 2.0 & $8 \mathrm{ng} / \mu \mathrm{l}$ \\
dNTP $(10 \mathrm{mM})$ & 0.5 & $0.2 \mathrm{mM}$ \\
$\mathrm{PCR}$ buffer $(5 \mathrm{X})$ & 5.0 & $1 \mathrm{X}$ \\
$\mathrm{MgCl}_{2}(25 \mathrm{mM})$ & 2.5 & $2,5 \mathrm{mM}$ \\
Primer $(10 \mathrm{pmol} / \mu \mathrm{l})$ & 1.0 & $0.4 \mu \mathrm{M}$ \\
$\mathrm{Taq} \mathrm{DNA}$ Polymerase $(5 \mathrm{U} / \mu \mathrm{l})$ & 0.2 & $1 \mathrm{U}$ \\
$\mathrm{ddH}_{2} \mathrm{O}$ & 13.8 & \\
\hline Total Volume & 25.0 & \\
\hline
\end{tabular}




\section{Data Analysis}

DNA bands were scored for presence (score 1) and absence (score 0 ). The data were then analyzed with NTsys software. Similarity analysis was done by using DICE coefficient (Nei \& Li, 1979). Unweighted pair group method with arithmetic mean (UPGMA) was used in clustering analysis to construct dendogram.

\section{RESULTS AND DISCUSSION}

Indonesian rodent tubers from Bogor, Pekalongan and Medan were analyzed by using 16 RAPD primers (Table 2). Among the primers used in this study, 12 out of 16 primers successfully showed polymorphism among Indonesian rodent tubers. Total DNA bands obtained in the study is 83 bands, 31 of them are polymorphic. Percentage of polymorphic bands obtained in this study was $37.3 \%$. DNA band size obtained in this study ranging between 200 bp to 2500 bp.

Table 2. Primer, Sequence, and DNA Bands Obtained from RAPD Amplification.

\begin{tabular}{ccccc}
\hline Primer & Sequence & Band size (kbp) & $\begin{array}{c}\text { DNA } \\
\text { Bands }\end{array}$ & $\begin{array}{c}\text { Polymorphic } \\
\text { DNA Bands }\end{array}$ \\
\hline OPA-02 & TGCCGAGCTG & $0.5-0.8$ & 3 & 2 \\
OPA-07 & GAAACGGGTG & $0.3-1.5$ & 7 & 1 \\
OPA-09 & GGGTAACGCC & $0.6-1.4$ & 5 & 2 \\
OPA-18 & AGGTGACCGT & $0.5-0.9$ & 3 & 1 \\
OPB-12 & CCTTGACGCA & $0.4-1.7$ & 6 & 2 \\
OPB-17 & AGGGAACGAG & $0.35-1.7$ & 4 & 2 \\
OPB-18 & CCACAGCAGT & $0.5-1,5$ & 6 & 1 \\
OPC-05 & GATGACCGCC & $0.5-2.0$ & 7 & 3 \\
OPC-08 & TGGACCGGTG & $0.3-2.0$ & 6 & 5 \\
OPC-11 & AAAGCTGCGG & $0.25-1.0$ & 6 & 4 \\
OPD-08 & GTGTGCCCCA & $0.2-2.0$ & 6 & 0 \\
OPD-10 & GGTCTACACC & $0.25-2.0$ & 5 & 5 \\
OPD-20 & ACCCGGTCAC & $0.6-2.5$ & 7 & 0 \\
OPE-03 & CCAGATGCAC & $0.25-0.75$ & 3 & 0 \\
OPE-15 & ACGCACAACC & $0.75-1.5$ & 3 & 0 \\
OPE-20 & AACGGTGACC & $0.4-1.5$ & 6 & 3 \\
\hline & Total & & 83 & 31 \\
\hline
\end{tabular}

Previous study of Typhonium genus plants had been done in India (Acharya et al., 2005; Rout, 2006). Acharya etal. (2005) obtained 233 polymorphic bands out of 245 bands (95\% polymorphic bands). Percentage of polymorphic bands obtained in this study was lower in comparison to the previous study. These data showed that cultivar level diversity of Indonesian rodent tuber is lower than species level diversity of Indian Typhonium species.

The results in Fig. 1- Fig. 4 showed the DNA bands profile of Indonesian rodent tuber in $1 \%$ agarose after separation by electrophoresis. Among all of the RAPD primers used in the study, amplification using OPC-08 produced the most polymorphic bands, which are 5 polymorphic bands out of 6 DNA bands (Figure 2). OPE-03 (Figure 3) and OPE-15 (Figure 1), on the other hand, both produced the fewest DNA bands, which are 0 polymorphic band out of 3 DNA bands. RAPD molecular markers successfully showed polymorphism among Indonesian rodent tubers used in this study. Aside from this study, RAPD molecular markers had also been used in several other studies to detect genetic diversity of plants, such as Vigna 
mungo (L.) Hepper (Arulbarachandran et al., 2010) dan Arachis hypogaea L. (Bhagwat et al. 1997).

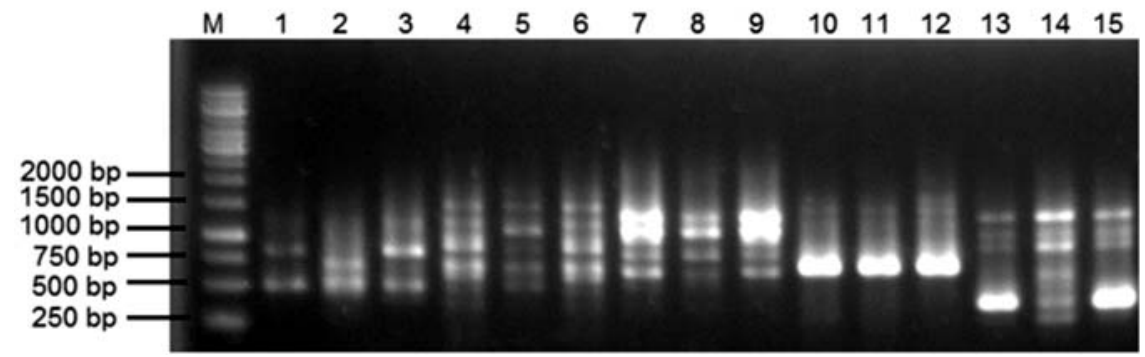

Figure 1. DNA Bands Profile of Indonesian Rodent Tubers based on RAPD Primer OPA-02, OPA07, OPB-18, OPE-15, and OPE-20

(M) 1kb ladder, (1) OPA-02 Bogor, (2) OPA-02 Pekalongan, (3) OPA-02 Medan, (4) OPA-07 Bogor, (5) OPA-07 Pekalongan, (6) OPA-07 Medan, (7) OPB-18 Bogor, (8) OPB-18 Pekalongan, (9) OPB-18 Medan, (10) OPE-15 Bogor, (11) OPE-15 Pekalongan, (12) OPE-15 Medan, (13) OPE-20 Bogor, (14) OPE-20 Pekalongan, (15) OPE-20 Medan.

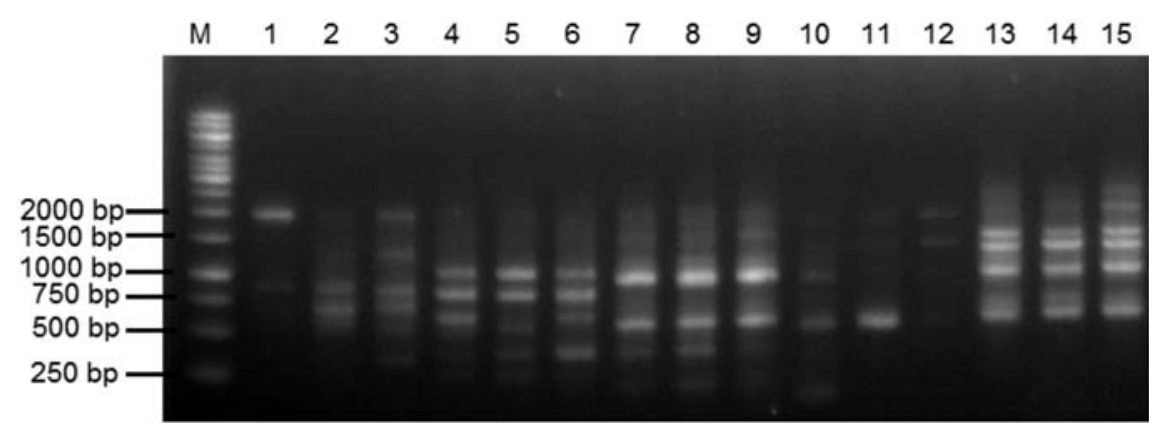

Figure 2. DNA Bands Profile of Indonesian Rodent Tubers based on RAPD Primer OPC-08, OPC-11, OPD-08, OPD-10, and OPD-20.

(M) 1kb ladder, (1) OPC-08 Bogor, (2) OPC-08 Pekalongan, (3) OPC-08 Medan, (4) OPC-11 Bogor, (5) OPC-11 Pekalongan, (6) OPC-11 Medan, (7) OPD-08 Bogor, (8) OPD-08 Pekalongan, (9) OPD-08 Medan, (10) OPD-10 Bogor, (11) OPD-10 Pekalongan, (12) OPD-10 Medan, (13) OPD-20 Bogor, (14) OPD-20 Pekalongan, (15) OPD-20 Medan.

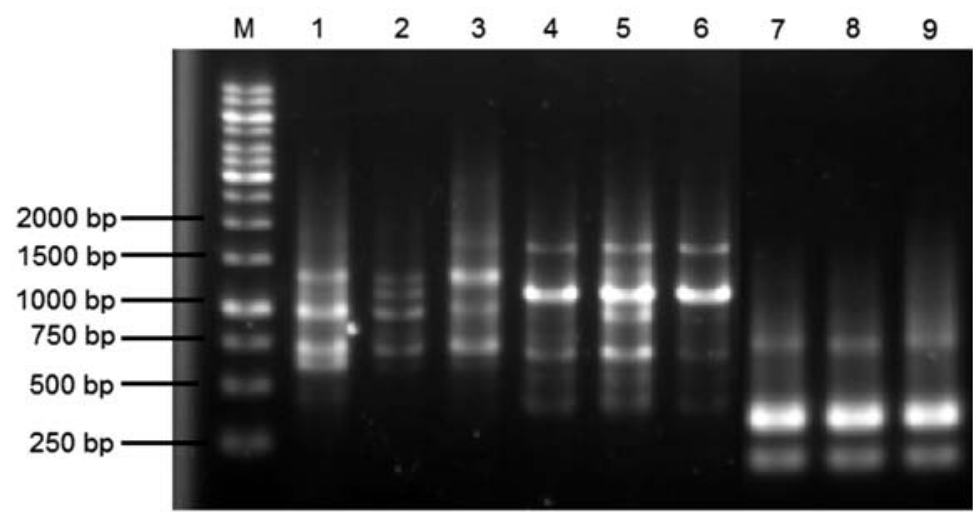

Figure 3. DNA Bands Profile of Indonesian Rodent Tubers based on RAPD Primer OPA-09, OPB12, and OPE-03

(M) 1kb ladder, (1) OPA-09 Bogor, (2) OPA-09 Pekalongan, (3) OPA-09 Medan, (4) OPB-12 Bogor, (5) OPB-12 Pekalongan, (6) OPB-12 Medan, (7) OPE-03 Bogor, (8) OPE-03 Pekalongan, (9) OPE-03 Medan. 


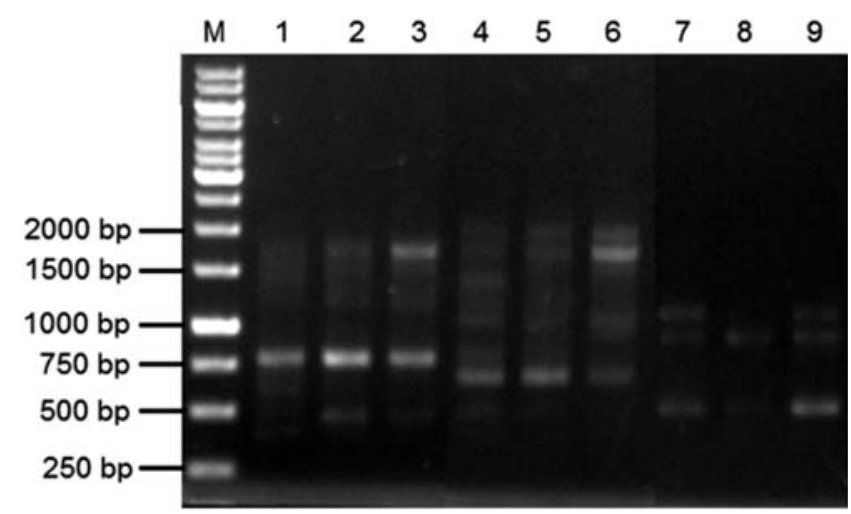

Figure 4. DNA Bands Profile of Indonesian Rodent Tubers based on RAPD Primer OPB-17, OPC05, OPA-18.

(M) $1 \mathrm{~kb}$ ladder, (1) OPB-17 Bogor, (2) OPB-17 Pekalongan, (3) OPB-17 Medan, (4) OPC-05 Bogor, (5) OPC-05 Pekalongan, (6) OPC-05 Medan, (7) OPA-18 Bogor, (8) OPA-18 Pekalongan, (9) OPA-18 Medan.

DNA bands obtained from RAPD amplification reaction were scored and analyzed by using NTsys software. Similarity analysis with DICE coefficient showed the relationship between each pair of rodent tuber cultivar (Table 3). The highest similarity obtained was $87 \%$ between Pekalongan and Medan cultivars. The lowest similarity obtained was $81 \%$ obtained between Pekalongan and Bogor cultivars. This result showed that rodent tubers from Bogor and Pekalongan genetically differ more than rodent tubers from Bogor and Medan based on 16 RAPD primers, even though geographically Bogor and Pekalongan are closer.

Table 3. Similarity Matrix (Nei and Li's Coefficient) of Indonesian Rodent Tubers based on RAPD Markers Analysis

\begin{tabular}{lrrr}
\hline & \multicolumn{1}{c}{ Bogor } & Pekalongan & Medan \\
\hline Bogor & 1.000 & & \\
Pekalongan & 0.812 & 1.000 & \\
Medan & 0.848 & 0.870 & 1.000 \\
\hline
\end{tabular}

Dendogram of Indonesian rodent tubers were obtained from clustering analysis (Figure 5). Cut off on genetic distance 0.85 produced two groups. The first group exclusively contained Bogor cultivar and the other contained Pekalongan and Medan cultivars.

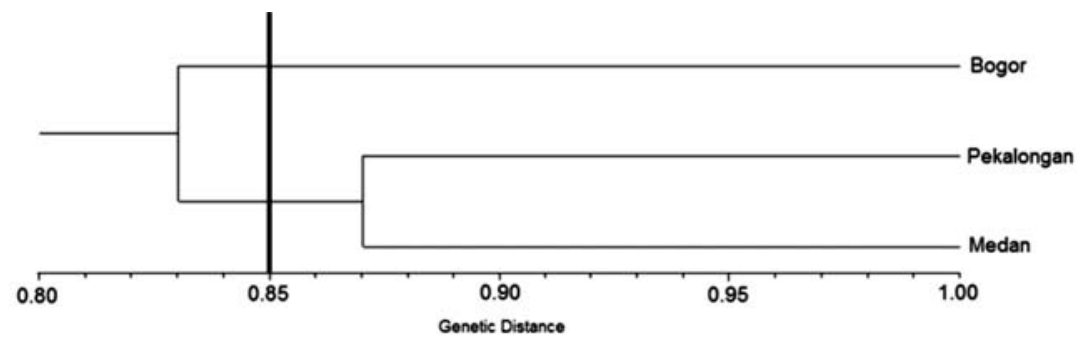

Figure 5. Dendogram of Indonesian Rodent Tuber based on RAPD Molecular Marker Analysis 


\section{CONCLUSION}

RAPD markers had been successfully used to show genetic diversity between three Indonesian rodent tuber cultivars. Additional information related to morphological traits of Indonesian rodent tuber would provide another input regarding Indonesian rodent tuber's genetic diversity.

\section{ACKNOWLEDGEMENT}

This research was funded by The Indonesian Directorate of General Higher Education (DIKTI) through Program Kreativitas Mahasiswa Penelitian (PKMP). Authors would like to thank DIKTI for the research funding support.

\section{REFERENCES}

Acharya, L., A.K. Mukherjee, P.C. Panda, and P. Das. 2005. Molecular characterization of five medicinally important species of Typhonium (Araceae) through random amplified polymorphic DNA (RAPD). Journal of Biosciences, 60:600-604.

Arulbalachandran, D., L. Mullainathan, S. Karthigayan, S.T. Somasundaram, and S. Velu. 2010. Genetic Variation in Mutants of Black Gram (Vigna mungo (L.) Hepper) Evaluated by RAPD Markers. Journal of Crop Science Biotechnology 13: 1-6.

Bhagwat, A., T.G. Krishna, and C.R. Bhatia. 1997. RAPD Analysis of Induced Mutants of Ground nut (Arachis hypogaea L.). Journal of Genetics 76: 201-208.

Chan, L.K., W.Y. Koh, and S. Tengku-Muhammad. 2005. Comparison of Cytotoxic Activities between in Vitro and Field Grown Plants of Typhonium flagelliforme (Lodd.) Blume. Journal of Plant Biology 48: 25-31.

Fauza, H., I. Ferita, M.H. Karmana, N. Rostini, and R. Setiamihardja. 2007. Variabilitas Genetik Tanaman Gambir Berdasarkan Marka RAPD. Zuriat, 18(2): 93-99.

Huang, P., G. Karagianis, and P.G. Waterman, P.G. 2004. Chemical constituents from Typhonium flagelliforme. Zhong Yao Cai 27(3): 173-175.

Mohan, S., A. Bustamam, S. Ibrahim, A. Al-Zubairi, M. Aspollah, R. Abdullah, and M.M. Elhassan. 2011. In vitro ultramorphological assessment of apoptosis on CEMss induced by linoleic acid-rich fraction from Typhonium flagelliforme tuber. Evidence-based Compelementary and Alternative Medicine 2011: 421894.

Nei, M., and W.H. Li. 1979. Mathematical model for studying genetic variation in terms of restriction endonucleases. Proceedings of the National Academy of Sciences of the United States of America 74:5267-5273.

Nurrochmad, A., E. Lukitaningsih, and E. Meiyanto, E. 2011. Anti cancer activity of rodent tuber (Thyphonium flagelliforme (lodd.) Blume on human breast cancer T47D cells. International Journal of Phytomedicine 3: 138-146

Rout, G.R. 2006. Evaluation of genetic relationship in Typhonium species through random amplified polymorphic DNA markers. Biologia plantarum 50 (1): 127-130.

Semagn, B.A., and M.N. Ndjiondjop. 2006. An overview of molecular merker methods for plants. African Journal of Biotechnology 5: 2540-2568.

Surachman, D. 2009. Penggunaan beberapa taraf konsentrasi paklobutrazol dalam media konservasi keladi tikus (Typhonium flagelliforme Lodd.) in vitro. Buletin Teknik 
Pertanian, 14(1): 31-33.

Syahid, S.F., and N.N. Kristina. 2007. Induksi dan regenerasi kalus keladi tikus (Typhonium flagelliforme. Lodd.) secara in vitro. Jurnal Littri, 13(4): 142-146. 